Download

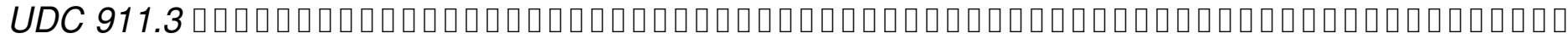

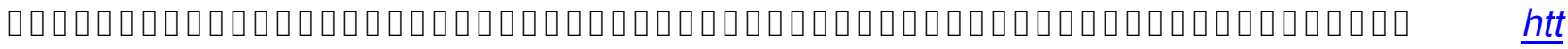
ps://doi.org/10.17721/2308-135X.2019.53.61-68

Bezugly Vitaly Viktorovych, Candidate Of Pedagogical Sciences, Associate Professor, Dnieper National University named after Oles Honchar, Dnipro, Ukraine,

e

mail

:vetalbezugly

$@$

ukr.net

Boyko Zoya Volodymyrivna, Candidate of Geographical Sciences, Associate Professor, Univer sity of Customs and Finance, Dnipro,

Ukraine

e

-

mail

zdor_zv@ukr.net.

Yarotskaya Alina Andriyivna, TOURBO event tour club, Dnipro, Ukraine 


\section{CURRENT STATE OF TOURISM INDUSTRY DEVELOPMENT IN INDIA}

The main purpose of the article - generalization of modern development of tourist industry of India, determination status and analysis of prospects of development of tourism sphere are in the economy of the country that develops (on the example of India).

Methodology. In the article such methods of geographical research were used as to the analysis, comparative, historical, statistical et al. On this basis, an analysis of the conditions and results of tourism development in India as a whole and in its administrative units was introduced due to statistics of certain indicators (number of foreign tourists, foreign currency arrivals, number of outbound tourists from India, number of hotels by category, number of restaurants business, etc.). The theoretical base of research labors of home specialists served as in the field of tourist country-specific studies (Baidik O., Maslyak P.). Statistical data of World Tourism Organization UNWTO and Ministries of statistics and implementation of the programs of India, that represented development of tourist sphere of India status, were widely used.

Results. The peculiarities of development of such a new and promising branch of the Indian economy as tourism are analyzed. The dynamics of the main indicators of the tourism industry in India (number of foreign tourists' arrivals and arrivals of foreign currency spent by tourists), for the years 2002-2018 and their impact on the effectiveness of the development of this sphere. Geospatial characteristics of tourism infrastructure in India are given, selected states of the country with the largest and smallest number of arrivals of foreign tourists to them. The specific composition and forms of activity of the hotel and restaurant sector of India are analyzed; it is revealed that the hotel sector forms a key segment of the tourism industry of the country. Prospects for development of India's tourism sector by 2025 have been determined.

Scientific novelty. It is an analysis of the tourism industry of India for the years 2002-2018 using various statistical methods. The ways of development and the place of the tourism industry in the developing country economy (on the example of India) are shown. 
Practical meaningfulness. The main promising steps required for the further gradual development of the tourism sector in India are outlined. The results of the research can be widely used both in lectures, as well as in practical and seminars in the study of disciplines of tourist country studies, in the preparation of specialists for the national tourism industry, the practical activity of Ukrainian tourist operators and agencies. The row of key positions that can be useful to development of tourist sphere of Ukraine is distinguished.

Keywords: India, tourism, tourism infrastructure, foreign tourists, investments, hotel and restaurant sector

References 1. Beydyk A.A., Greshnyakova T.V. Indiya v ob'yedinenii BRIK: turisticheskoye i zmereniye

/l

Geografiya

i

turizm

:

Nauchn

$\mathrm{sb}$

-

$\mathrm{K}$

., 2011. -

Vyp

.12. -

$\mathrm{S}$

$.133-138$.

2.

Global'naya baza dannykh rynochnykh issledovaniy Euromonitor International [Elektronnyy resurs] / Rezhim dostupa:

https://www.euromonitor.com/

3.

Konsaltingovoye agentstvo Oxford Economics [Elektronnyy resurs] / Rezhim dostupa:

https://www.oxfordeconomics.com

4. Ofitsial'nyy sayt Vsemirnoy turisticheskoy organizatsii [Elektronnyy resurs] / Rezhim dostupa: http://www.unwto.org/ 5 . Ofitsial'nyy sayt Ministerstva statistiki i vypoleniya programm Indii [Elektronnyy resurs] / Rezhim dostupa: tp://mospi.gov.in/ 
6. Ofitsial'nyy sayt Ministerstva turizma Indii [Elektronnyy resurs] / Rezhim dostupa: http://touris m.gov.in/

7. International Tourism Highlights. UNWTO. Retrieved 8 September 2019 [Elektronnyy resurs] / Rezhim dostupa: $\quad$ https://www.e-unwto.org/doi/pdf/10.18111/9789284421152 8. T he Travel \& Tourism Competitiveness Report 2017 [Elektronnyy resurs] // Rezhim dostupa: http://www3.weforum.org/docs/WEF_TTCR_2019.pdf 